DOI 10.18551/rjoas.2019-05.03

\title{
TECHNICAL AND FINANCIAL ANALYSIS OF BLUE SWIMMING CRAB (PORTUNUS PELAGICUS) FISHING BUSINESS IN REMBANG DISTRICT, INDONESIA
}

\author{
Principal Etha Anaesthesia*, Student \\ Graduate Program of Coastal Resource Management, Faculty of Marine and Fisheries, \\ University of Diponegoro, Indonesia
}

Saputra Suradi Wijaya, Purwanti Frida, Lecturers

Department of Aquatic Resources, Faculty of Marine and Fisheries, University of Diponegoro, Indonesia

${ }^{\star}$ E-mail: principal3010@gmail.com

\begin{abstract}
This research analysed the technical and financial aspects of blue swimming crab fishing business using folding tray in Tunggul Sari, Rembang District, Indonesia. This research was conducted from February to March 2016. The samples of this descriptive research were selected using purposive sampling method. The obtained data were then analysed based on business feasibility analysis using some indicators including NPV, IRR, payback period and $\mathrm{R} / \mathrm{C}$ Ratio. The results of the technical analysis showed that fishermen employed folding trays with single size (Length $x$ width $x$ height: $45 \mathrm{~cm} \times 30 \mathrm{~cm} \times 18 \mathrm{~cm}$ ), yet they applied different numbers of folding trays, ranging between $500-600$ trays. They also had similar size of fishing boats under 5 GT and they applied one day fishing system. Meanwhile, the results of the financial analysis showed Net Present Value $>0$, amounted to IDR 94.691.087 per month, Internal Rate of Return of $45.56 \%$ greater than the interest rate of $12 \%$, payback period of 3 years 3 months and 3 days and R/C ratio $>1$ at 1.20. Regarding to those results, the blue swimming crab fishing business run using folding tray in Tunggul Sari has been regarded feasible.
\end{abstract}

\section{KEY WORDS}

Blue swimming crab, folding trap, technical asset, financial asset, Tunggul Sari, Rembang.

Rembang is a district located in the northern shore of Central Java Province, Indonesia. This district possesses marine potentials that play major role to its economic development. The production of blue swimming crab in Rembang District also ranked the big 3 in Central Java Province after Demak District and Kebumen District, with a total yearly production of 512.5 tons, 258 tons, and 198 tons respectively (DKP of Central Java Province, 2017).

Blue swimming crab is also a major export commodity to the United States of America. The production of blue swimming crab greatly depends on the catches of fishermen from the sea. Blue swimming crab is the main catch and secondary catch of certain fishing tool. According to KEPMEN-KP Number 70 of 2016, there are many methods or tools used to catch the crab as the main target and as secondary target as well including: 1) Fish Trap: folding trap; 2) Fishing nets: crab nets and trammel net; 3) Seine Nets: Danish seine, cantrang, payang; 4) Trawl; and 5) Dredges. Trammel net and traps were mostly used by fishermen in Rembang as presented in Figure 1.

Based on Figure 1, the most used tool among fishermen in Rembang is trammel net and trap. Both tools shared slightly similar percentage with only one percent different. Meanwhile, the use of cantrang, Danish seines, lampara and payang shows low percentage as the trawls and seine nets are banned for use in WPPNRI (Wilayah Pengelolaan Perikanan Negara Republik Indonesia) or Indonesian Fishing Management Area. 


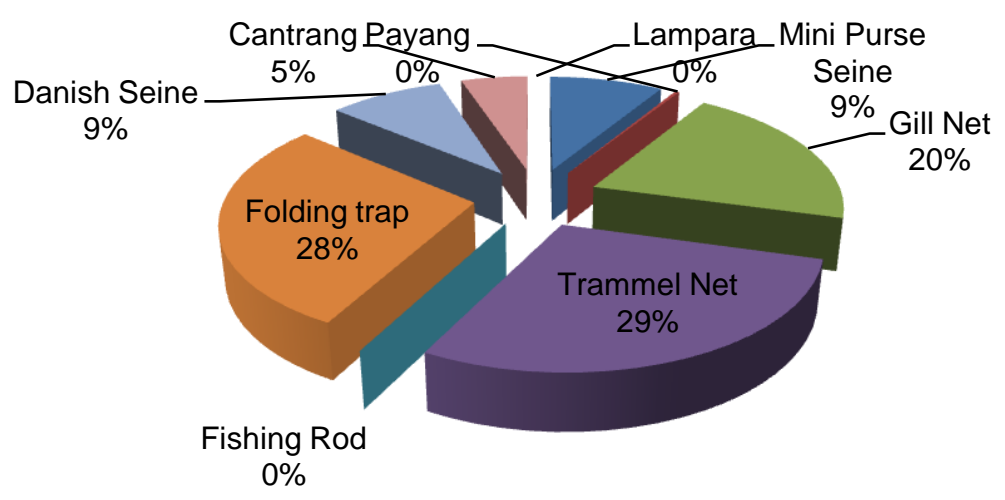

Figure 1 - The Percentage of Fishing Tool Use in Rembang District 2017 (Source: The Department of Marine and Fisheries of Rembang District, 2018)

Traps in the form of folding traps are mostly used to catch the blue swimming crab. The use of particular trap in an area as pointed out by Martasuganda (2008) is mostly affected by considerations on the costs in the making of the tool, easiness in operating the tool, the condition of the catches in which living catches have higher economical values than the dead ones, and the ban upon the use of certain tool other than traps. The folding trap is a fish trap that belongs to the group of traps.

Tunggul Sari village is a fishermen village in Kaliori Regency of Rembang District, where people catch the blue swimming crabs using folding traps as their daily business. They have been running their activities for more than 10 years. The high demand upon the blue swimming crab drives the fishermen to continuously catch the crabs. They catch the crabs on daily basis all year long without any particular day off but only when their neighbours held certain occasion or funerals. Any sizes of the crabs are accepted by collectors. Regarding to the use of folding traps to catch the blue swimming crabs, technical analysis and financial analysis to the business was considered necessary to conduct.

This research was conducted to analyze the technical aspect of crab fishing using folding traps and to analyze the financial aspects of the crab fishing business using folding traps in Tunggul Sari Village, Kaliori Regency of Rembang District.

\section{METHODS OF RESEARCH}

This research was conducted from February - March 2018 in Tunggul Sari Village, Kaliori Regency, Rembang Province, Central Java Province. The location was purposively selected as fishermen in this village used folding traps. The village has been selected for many times as a pilot village for research done by the Department of Marine and Fisheries of Rembang District for its blue swimming crab production.

Primary and secondary data were collected in this research. Primary data were collected through observations, interviews and documentations, while secondary data were obtained from the Department of Marine and Fisheries of Rembang District. Observations were carried out in the form of direct observation toward the research object. The objects of this research included the construction of folding traps, fishing boats and fish catches. Direct interviews were administered with fishermen who used folding traps as the respondents based on questionnaires. The data obtained from the interviews were related to technical and financial aspects of the blue swimming crab business. Furthermore, documentation was done by taking pictures directly during the research.

The descriptive method employed in this research allowed the researchers to describe the technical and financial aspects of the crab fishing business using folding traps.

Samples were selected using the purposive sampling technique. As explained by Sugiyono (2013), pulDRosive sampling technique is a technique used to take samples from data sources based on particular considerations such as the samples are considered 
capable in providing rich information relating to the research which are then expected to make it easier for researchers to explore the object or social phenomena being observed. Samples in this research were determined based on the minimum sample requirement of 30 respondents.

The analysis of technical data was conducted descriptively including the construction of the traps, fishing boats and the operating procedure of the folding traps.

According to Umar (2009), Net Present Value is measured based on the following formula.

$$
\mathrm{NPV}=\sum_{\mathrm{t}=1}^{\mathrm{n}} \frac{\mathrm{CFt}}{(1+\mathrm{i}) \mathrm{t}}-\mathrm{Co}
$$

Where: $\mathrm{n}$ - Number of year; $\mathrm{t}$ - year-t; CFt - Cash flow per year in period $\mathrm{t}$; Co - Initial investment in year-0; i - Interest rate. Decisions: NPV $>1$, the project is accepted; NPV $=1$, the company remains stable despite project is accepted or rejected; NPV $<1$, the project is rejected.

As stated by Umar (2009), Internal Rate of Return is one of methods to measure the level of investment. IRR is measured using the following formula.

$$
\mathrm{Io}=\sum_{\mathrm{t}=1}^{\mathrm{n}} \frac{\mathrm{CFt}}{(1+\mathrm{IRR})^{t}}
$$

Where: Io - Initial investment value; $\mathrm{t}$ - Year-t; $\mathrm{n}$ - Number of year; CFt - Net cash flow; IRR Internal rate of return.

Effendi (2006) stated that the analysis of payback period is intended to find out the estimated time of return on investment made by certain company. Generally, the payback period is calculated as follows.

$$
\mathrm{PP}=\frac{\text { Total investment } \times 1 \text { year }}{\text { Profit }}
$$

Revenue cost ratio is a common and simple concept to measure business feasibility (Ramadhan et al., 2017). Effendi (2006) explained that R/C analysis is employed to calculate the relative profit of a company on year compared to the operational cost. A business is regarded feasible if $R / C$ is greater than $1(R / C>1)$. It implies that the greater the $R / C$, the greater the profit. $\mathrm{R} / \mathrm{C}$ ratio analysis can be measured using this following formula:

$$
\mathrm{R} / \mathrm{C}=\frac{\text { Total Income }}{\text { Total Fixed Cost }+ \text { Total Variable Cost }}
$$

\section{RESULTS AND DISCUSSION}

Folding traps is a tool used to catch fish in the WPPNRI which belongs to the traps. Traps are made from net, and/or steel, wood, bamboo and they shape cylindrical, trapezium and other shapes that can be operated passively with or without bait in the bottom or water surface (KEPMENKP Number 10 of 2010). The folding trap is designed to trap the target fish to enter the door without being able to come out. Folding trap is a passive tool put in particular place without interruption as it lures the target to come into the trap (Shalichaty et al., 2014). The folding trap is employed by all fishermen in Tunggul Sari village as it is easy to operate and it is foldable that fishermen are able to bring many traps at once. In one fishing unit, fishermen applied around $500-600$ units, in which flagship called umpal was put in every 50 units. Umpal is applied to anticipate losses as traps are applied in one series. This number of traps applied by fishermen exceeded the maximum traps of 300 units as allowed by PERMEN-KP Number 71 of 2016 Article 30 verse 2. The number of traps should 
be well-regulated to avoid excessive fishing. Besides, folding trap is an economic and lowcost trap to make compared to other crab traps such as gillnet and arad.

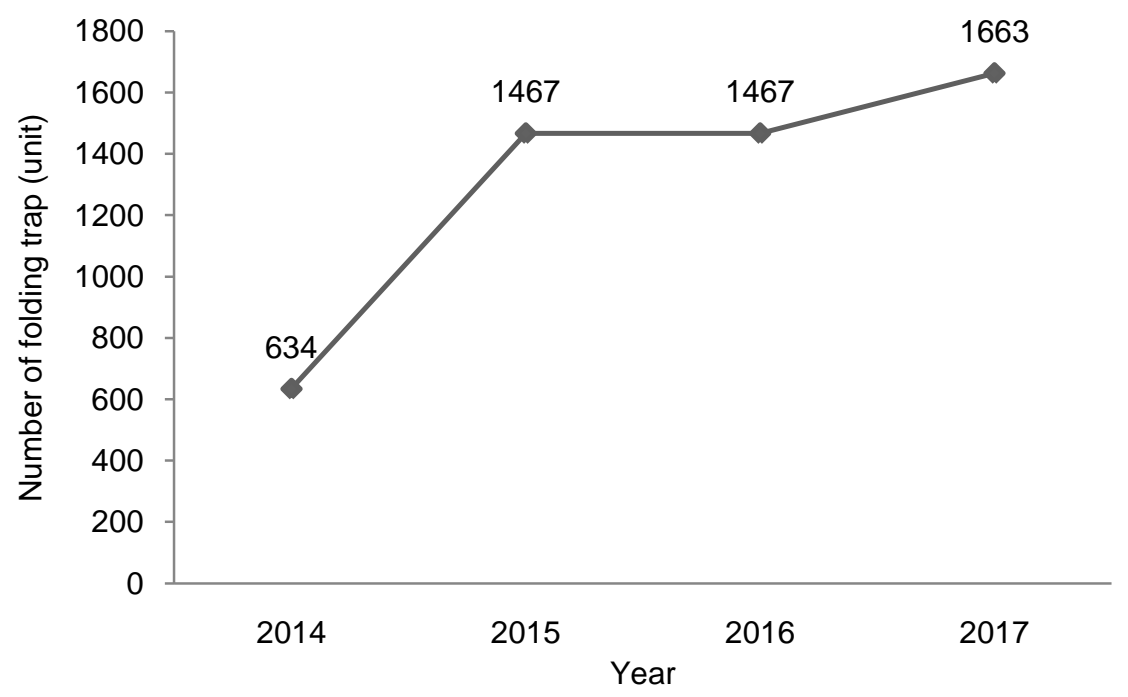

Figure 2 - The Trend of Using the Folding Trap in Rembang District from 2014-2017

(Source: The Department of Marine and Fisheries of Rembang District, 2018)

Figure 2 shows that between 2014-2017, the trend of using the folding trap increased. This increase occurred as fishermen wanted to increase the quantity of their catches which led to higher earnings.

The folding trap used by fishermen in Tunggul Sari Village is square-shaped made from steel and covered by Polyethylene (PE) nets. The detail size of the trap is presented in Table 1.

Table 1 - The Results of Observation on the Construction of Folding Trap

\begin{tabular}{|c|c|c|c|c|c|c|c|}
\hline Measured Part & Direction of the Twist & Length & Width & Height & Net Mesh Size & Color & Material \\
\hline Body & - & $45 \mathrm{~cm}$ & $30 \mathrm{~cm}$ & $18 \mathrm{~cm}$ & & - & Fe \\
\hline Nets & Z & - & & - & $1.25 \mathrm{~cm}$ & Green & PE \\
\hline Trap Door & - & $30 \mathrm{~cm}$ & $2 \mathrm{~cm}$ & - & & - & - \\
\hline Main Rod & $\mathrm{S}$ & $3.5 \mathrm{~km}$ & - & - & & White & PE \\
\hline Branch Rod & Z & $1 \mathrm{~m}$ & - & - & & Blue & PE \\
\hline
\end{tabular}

Based on Table 1, the size of the folding trap body is $45 \times 30 \times 18\left(\mathrm{~cm}^{3}\right)$. Almaida et al. (2015) stated that the size $(\mathrm{p} \times \mid \times \mathrm{t})$ of the folding trap body used by fishermen is $43 \times 30 \times$ $18\left(\mathrm{~cm}^{3}\right)$, similar to the one used in Betah Walang Village, Demak Regency. One unit of folding trap is strung together on one main rope with a total of $500-600$ units. Based on Table 1 above, the total length of the main rope of the folding trap ranges up to $3.5 \mathrm{~km}$ while the branch rope is $1 \mathrm{~m}$ in size. The main rope used between fishermen can be different as the total length of the main rope depends on the number of folding traps and the distance between the traps. The number of folding traps installed by each fisherman depends on the financial capacity of the fishermen.

Folding traps are usually operated by fishermen in Tunggul Sari Village using 5 GT wooden boats with $6.4 \mathrm{~m}$ length, $2.6 \mathrm{~m}$ width and $0.9 \mathrm{~m}$ tall. Their boats are equipped with Donfeng engine with 16 PK power. There are usually 3 crews on boat including 1 owner who is usually the captain, and 2 crews.

The blue swimming crabs are usually caught using one day fishing method due to the relatively near distance toward the fishing ground and the need to immediately collect the crabs to the collectors for further process. Fishermen usually start catching the crabs using the folding traps in the dawn or around 04.00 West Indonesia Time up to $09.00-11.00$ West 
Indonesia Time. The total time needed for a trip ranges from 5 to 7 hours. These followings are the steps to operate the folding traps.

The planning step includes checking the fuel (diesel), boat condition, bait and boat crews. Fishermen usually determine the fishing ground based on their experience for years in catching the crabs. They usually do it in the northern water of Marongan Island to the northern part of Muara Sungai Juana around 4-12 miles away from the shore and 5-10 m in depth. The trip from the fishing base to the fishing ground takes around 1-3 hours. Baits are put in the traps during the trip to the fishing ground. The baits are usually made from Swanggi fish head, processed cow leather, even banana tree midrib.

Setting or the application of the trap is done when fishermen have reached the fishing ground. They start by reducing the engine speed, applying the flag buoy in the water, applying the traps one by one in every $7-7.5$ meter gap between each trap, applying the ballast and applying the sign buoy.

Immersing is done by soaking the traps and letting the traps under the water for one day and one night to lure the crabs with the baits and to get them trapped. The baits have to stay long in the water as crabs are lured by them. Baits made from Swanggi fish are the most popular baits. The immersing time might differ based on the area. As stated by Pratama et al. (2012), the immersing time takes around 3-4 days. Longer immersing time might be caused by the location of fishing ground that is farther.

Hauling is done once a day. If traps are put in 06.00 in the morning, the hauling is done around 05.00 the next day. Hauling is done to take the catches. During the hauling process, fishermen do not employ any tools, making the time less efficient compared to the time needed when they use supporting tools. According to Ubaidillah (2014), the use of line hauler in the main rope of the traps makes hauling process easier in every trip.

After every hauling, each trap is cleaned, and other bait is put to be settled and immersed back. The cycle is done all year long. Broken traps are brought to the base to be fixed and put back. The main target of the traps is the blue swimming crabs. Regardless of the quantity, the catches are then collected to the collectors. A research done by Muawanah et al. (2017) also mentioned that almost all of the crabs are accepted by collectors or mini plants to be later sold to crab exporters.

The financial aspects of the blue swimming crab fishing business using the folding traps strongly correlates with capital investment and working capital that should be analysed in determining the feasibility of the business.

Capital investment is the initial capital needed for an emerging entelDRrise to run its production process. Capital investment in this business included wooden boat, boat engine, and folding traps. The detail items of the capital investment are described in Table 2.

Table 2 - The Average Capital Investment of Crab fishing Business using the Folding Traps

\begin{tabular}{|c|c|c|c|c|c|}
\hline No & $\begin{array}{c}\text { Types of } \\
\text { Investment }\end{array}$ & $\begin{array}{c}\text { Economic Age } \\
\text { (Year) }\end{array}$ & $\begin{array}{c}\text { Minimum } \\
\text { (Rupiah/Year) }\end{array}$ & $\begin{array}{c}\text { Maximum } \\
\text { (Rupiah/Year) }\end{array}$ & $\begin{array}{c}\text { Average } \\
\text { (Rupiah/Year) }\end{array}$ \\
\hline 1 & Boat & 10 & $27,000,000$ & $35,000,000$ & $31,000,000$ \\
\hline 2 & Engine & 5 & $5,000,000$ & $8,000,000$ & $6,500,000$ \\
\hline 3 & Folding Traps & 3 & $12,000,000$ & $18,900,000$ & $15,450,000$ \\
\hline \multicolumn{2}{|r|}{ Total } & $44,000,000$ & $61,900,000$ & $52,950,000$ \\
\hline
\end{tabular}

Based on Table 2, the biggest investment is put in the boat, while the smallest one is in the engine. The boats are commonly 5 GT in size with 16 PK powered Donfeng outboard engine. Capital investment has an economic life of more than one year. The economic life of the boat is 10 years. Therefore, in the 11th year re-investment should be carried out. The economic life of the engine is 5 years and needs re-investment in the 6th year. The economic life of folding traps is 3 years and re-investment is needed in the 4th year. Adequate capital is necessary in starting a business

The capital needed to run the business is around IDR 44,000,000 minimum and a maximum of IDR $61,900,000$. This amount can be reduced by procuring used boats and engines and fewer number of folding traps. Based on the results of interviews with 
fishermen, each fisherman has around 500 to 600 pieces of traps, which they install on fishing ground with the price of folding unit ranging from IDR 24,000 to IDR 27,000.

Working capital in the crab fishing business refers to the capital needed to do fishing activities. Working capital is permanent and non-fixed. Fixed working capital refers that the year the costs incurred are fixed such as the cost of maintenance and sea alms. Meanwhile, non-permanent working capital means the costs vary within a year such as crew wages, diesel fuel and bait costs. Table 3 presents the detailed item of the working capital.

Table 3 - Average Working Capital of Crab fishing Business using the Folding Traps

\begin{tabular}{|c|c|c|c|c|}
\hline No & Types of Working Capital & $\begin{array}{c}\text { Minimum } \\
\text { (IDR/Year) }\end{array}$ & $\begin{array}{c}\text { Maximum } \\
\text { (IDR/Year) }\end{array}$ & $\begin{array}{c}\text { Average } \\
\text { (IDR/Year) }\end{array}$ \\
\hline 1 & Maintenance Cost & $4,400,000$ & $6,190,000$ & $5,295,000$ \\
\hline 2 & Traditional ceremony of fishery & 300,000 & 300,000 & 300,000 \\
\hline 3 & Crew Wages & $56,094,420$ & $59,760,660$ & $57,927,540$ \\
\hline 4 & Diesel Fuel & $9,302,400$ & $10,852,800$ & $10,077,600$ \\
\hline 5 & Bait & $22,800,000$ & $27,360,000$ & $25,080,000$ \\
\hline & Total & $92,896,820$ & $104,463,460$ & $98,680,140$ \\
\hline
\end{tabular}

Based on Table 3, crew wages dominate the expenses, while marine charity has the smallest cost. Crew wages are distributed using profit sharing system with a proportion of $60 \%: 40 \%$, in which $60 \%$ goes to the fishermen while the $40 \%$ goes to the owners. The amount of wages for the crew depends on the number of catches obtained. More catches leads to higher amount of wages. The diesel fuel used for each trip ranges from 5-6 liters, in a year there are around 304 trips. More trips in a year leads to higher amount of capital spent on diesel fuel. The bait used in each trip ranges from 10-12 kg. More folding traps installed means more bait needed and higher amount of capital spent. The commonly used bait is the Swanggi fish head, although it can also be changed to processed cowhide even banana tree midrib. The use of banana leaf midrib as baits can reduce the amount of the working capital, but the crabs do not really like the baits compared to Swanggi fish head bait. The cost of crew consumption on each fishing trip, which includes food, drink and cigarettes, is borne by each crew. The crab fishing business does not require need ice to store the catches as it is done in a one day fishing system to maintain the quality. The average annual working capital is approximately IDR. 98,680,140.

The revenue of this business is obtained from the number of catches multiplied by the price. The price of crab is determined by collectors instead of fishermen because there is a capital bond between collectors and fishermen. Collectors usually provide capital investment assistance as a bond that fisherme collect their catches only to the collectors. The average crab price in the peak season is IDR. 55,000, IDR. 60,000 in non-peak season and in the dry season are around IDR. 76,000. The total average revenue is presented in Table 4.

Table 4 - The Average Revenue of the Crab fishing Business using the Folding Traps

\begin{tabular}{|c|c|c|c|c|c|}
\hline No & Season & Price Per Kg & Number of Trips & Average Production Per Trip & Revenue (IDR/Year) \\
\hline 1 & Peak Season & 55,000 & 83 & 16,50 & $75,322,500$ \\
\hline 2 & Ordinary Season & 60,000 & 126 & 5,50 & $41,580,000$ \\
\hline 3 & Low Season & 76,000 & 95 & 2,05 & $14,333,600$ \\
\hline \multicolumn{7}{|c|}{ Total Average Revenue $=$} \\
\hline
\end{tabular}

The revenue is influenced by the season. As presented in Table 4, the highest income is obtained during the peak season amounted to IDR 75,322,500 per year. Meanwhile, the lowest revenue is obtained in the dry season of around IDR. 14,333,600. During the peak season, fishermen can catch many crabs but the price is rather low and vice versa, during the dry season, the number of catches decreases but the price is higher. The crab peak season occurs from December to February, while the low season occurs from August to November.

Profit is the goal to be achieved in running a business. In general, a business is said to obtain profit if the revenue is greater than the total cost incurred and is said to suffer a loss if 
the revenue is smaller than the total cost. The profit of the crab fishing business using folding traps is presented in Table 5.

Table 5 - Profit/Loss of the Blue Swimming Crab Fishing Business in the First Year

\begin{tabular}{|c|c|c|}
\hline No & Item & Value (IDR) \\
\hline 1 & Revenue & $131,703,500$ \\
\hline 2 & Capital Investment & $52,950,000$ \\
\hline 3 & Working Capital & $98,680,140$ \\
\hline & Profit/Loss & $-19,926,640$ \\
\hline
\end{tabular}

Based on Table 5, the gap between revenue and capital is negative, indicating that the business suffers a loss. Loss in the first year is reasonable in a business, because there is a very large capital invested in the first year.

The feasibility of crab fishing business is measured in the form of financial analysis by calculating NPV, IRR, PP and R / C Ratio and several other assumptions relating to cash flow. The assumptions used in estimating the cash flow of the crab fishing business in Tunggul Sari Village are as follows:

- Project sustainability in 10 years;

- Capital investment, working capital and revenue increase by $10 \%$ per year;

- Capital comes from private capital, no bank loan is used;

- The remaining capital in the end of an economic year is around $30 \%$, which means that if the average investment for the engine (see Table 2) is IDR 6,500,000, and it is sold in the fifth year (5 year economic year), the remaining asset is $30 \%$, then the selling price of the engine is $1,950,000$, and reinvestment is made in the beginning of the $6^{\text {th }}$ year;

- Revenue is obtained from the sales of the crab and the remaining capital investment.

- $12 \%$ discount factor.

Table 6 - Financial Analysis of Blue Swimming Crab Fishing Business

\begin{tabular}{|c|c|c|}
\hline No & Item & Value (IDR) \\
\hline 1 & Cash flow (IDR) & - \\
\hline & Year -1 & $-47,029,354$ \\
\hline & Year -2 & $10,239,500$ \\
\hline & Year -3 & $33,536,000$ \\
\hline & Year -4 & $12,459,500$ \\
\hline & Year -5 & $33,811,500$ \\
\hline & Year -6 & $30,523,300$ \\
\hline & Year -7 & $14,419,000$ \\
\hline & Year -8 & $36,880,000$ \\
\hline & Year -9 & $44,934,300$ \\
\hline & Year -10 & $44,456,300$ \\
\hline 2 & Discount factor (\%) & 12 \\
\hline 3 & NPV (IDR) & $94,691,087$ \\
\hline 4 & IRR (\%) & $45,56 \%$ \\
\hline 5 & PP & 3 years 3 months 3 days \\
\hline 6 & R/C ratio & 1,20 \\
\hline
\end{tabular}

Based on Table 6, the NPV value of the business reaches IDR. 94,691,087, which means that at the end of the project, the profit obtained is IDR. 94,691,087. This NPV value is obtained by comparing the cash inflows (cash in) with the cash outflow (cash out) that has been value-presented. The interest rate is $12 \%$ in accordance with the micro business interest rate applies by Bank Rakyat Indonesia. Positive NPV value indicates that the business is profitable and feasible to run.

Business is said feasible if the IRR is greater than the discount factor and vice versa. Smaller IRR value than the discount factor implies that the business is not feasible. Based on Table 6 , the IRR value of the business is $45.56 \%$ with a discount factor of $12 \%$. The IRR 
value of this business is greater than the discount factor. Therefore, the crab fishing business using folding traps in Tunggul Sari Village is profitable and feasible to run.

Payback Period is an parameter that shows the rate of return on capital investment of a business. Faster return on investment capital is more preferable because it shows smooth capital flow. Based on table 6, the payback period of the crab fishing business is 3 years 3 months 3 days, which is considered fast. If the rate of return on capital is faster than the predetermined period, the business is considered feasible.

This analysis is obtained by comparing the income and the costs that incur. As presented in Table 6 , the $R / C$ value of the ratio of the business is 1.20 . The value of $R$ / $C$ ratio is $>1$, implying that the business is considered profitable and feasible to run. According to Malik (2013), increasing the R / C Ratio can be done by reducing the production costs by not using bait.

\section{CONCLUSION AND RECOMMENDATIONS}

Technically, fishermen in the researched location used folding traps with single size (length $x$ width $x$ depth: $45 \mathrm{~cm} \times 30 \mathrm{~cm} \times 18 \mathrm{~cm}$ ) but each fishermen applied different number of traps, ranging from $500-6$ traps. They also used similar boat size of under 5 Gross Ton using a one day fishing system.

From the financial point of view, the crab fishing business using folding traps in Tunggul Sari Village is considered feasible as NPV $>0$ amounted to IDR 94,691,087, IRR $(45.56 \%)$ greater than the interest rate of $12 \%$, payback period of 3 years 3 months 2 days and $\mathrm{R} / \mathrm{C}$ ratio $>1$ at 1.20 .

Based on PERMENKP No. 71 of 2016 concerning Fishing Lines and Placement of Fishing Equipment in the Fisheries Management Areas of the Republic of Indonesia, states that traps may be operated in IA, IB and II fishing grounds with a maximum of 300 traps. it is necessary to regulate the number of traps applied in one series. Based on the results of the study, the number of traps applied in a ground ranges from 500-600 traps. Without proper regulation and control upon the number of the traps, excessive exploitation of crab might occur, threatening the crab production. This problem will later affect the sustainability of the crab fishing business in Tunggul Sari Village.

\section{ACKNOWLEDGEMENTS}

Gratitude is expressed to the Head of Tunggul Sari Village and the Head of Fishermen Community of Tunggul Sari Village, Kaliori Regency, Rembang District and all parties who gave their contribution to the completion of this article.

\section{REFERENCES}

1. Almaida, S., D. Wijayanto, \& A. Ghofar. 2015. Analisis Perbandingan Pendapatan Nelayan Bubu Desa Betahwalang Dengan Pola Waktu Penangkapan Berbeda. Journal of Fisheries Resources Utilization Management and Technology. Vol. 4(3):1-9.

2. DKP [Dinas Kelautan dan Perikanan] Kabupaten Rembang. 2018. Statistik Kelautan dan Perikanan Kabupaten Rembang Tahun 2017.

3. DKP [Dinas Kelautan dan Perikanan] Provinsi Jawa Tengah. 2017. Statistik Perikanan Tangkap Jawa Tengah Tahun 2016.

4. Effendi, I. \& W. Oktavia. 2006. Manajemen Agribisnis Perikanan. Penebar Swadaya. Depok.

5. Malik, F.R. 2013. Kajian Beberapa Disain Alat Tangkap Bubu Dasar di Perairan Kepulauan Ternate Provinsi Maluku Utara. Jurnal IImiah Agribisnis dan Perikanan. Vol. 6(1): 52-57.

6. Martasuganda, S. 2008. Bubu (Traps). Departemen Pemanfaatan Sumberdaya Perikanan dan Pusat Kajian Sumberdaya Pesisir dan Lautan, Institut Pertanian Bogor. 
7. Muawanah, U., H.M. Huda, S. Koeshendrajana, D. Nugroho, Z. Anna, Mira \& A. Ghofar. Keberlanjutan Perikanan Rajungan Indonesia: Pendekatan Model Bioekonomi. 2017. Jurnal Kebijakan Perikanan Indonesia. Vol. 9 (2): 71-83.

8. Nazir, M. 2009. Metode Penelitian. Jakarta: Ghalia Indonesia.

9. Pratama, F.A., H. Boesono \& T.D. Harsanti. 2012. Analisis Kelayakan Finansial Usaha Penangkapan Ikan Menggunakan Panah, Bubu Dasar di Perairan Karimunjawa. Journal of Fisheries Resources Utilization Management and Technology. Vol. 1(1): 22-31.

10. Ramadhan, A.. 2017. Indeks Sosial Ekonomi Rumah Tangga Nelayan Indonesia. Jurnal Sosial Ekonomi Kelautan Perikanan. Vol. 12(2): 235-253.

11. Shalichaty, S.F., A.K. Mudzakir \& A. Rosyid. 2014. Analisis Teknis Dan Finansial Usaha Penangkapan Rajungan (Portunus pelagicus) Dengan Alat Tangkap Bubu Lipat (Traps) Di Perairan Tegal. Journal of Fisheries Resources Utilization Management and Technology. Vol. 3(3): 37-43.

12. Sugiyono. 2013. Metode Penelitian Kuantitatif, Kualitatif dan R\&D. Bandung: CV Alfabet.

13. Ubaidillah, F., H. Boesono \& Pramonowibowo. 2014. Perbedaan Lama Penarikan Hasil Tangkapan pada Pengoperasian Bubu Rajungan (Portunus $\mathrm{sp}$ ) dengan Rancang Bangun Alat Penarik Tali Utama di Desa Betahwalang kabupaten Demak. Journal of Fisheries Resources Utilization Management and Technology. Vol. 3(2): 1-8.

14. Umar, H. 2009. Studi Kelayakan Bisnis Edisi 3 Revisi. Jakarta: PT Gramedia Pustaka Utama. 